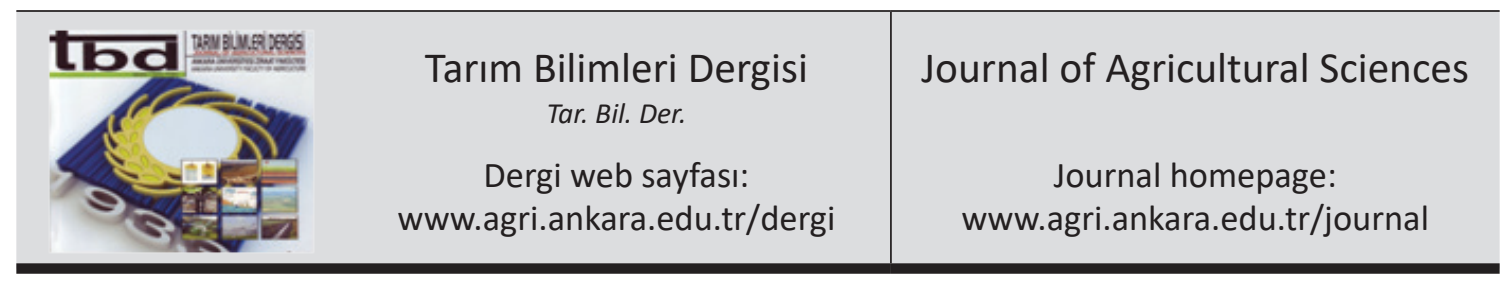

\title{
Drip Fertigation In Apple Orchards: Impact on Soil Chemical Properties and Nutrient Distribution In Relation to Soil Texture
}

\author{
Ranko ČABILLOVKİa, Aboubaker BRAYEK ${ }^{a}$, Nenad MAGAZİNa, Borivoj PEJIĆá, Klara PETKOVIĆa, \\ Maja MANOJLOVİ́c \\ ${ }^{a}$ University of Novi Sad, Faculty of Agriculture, Trg Dositeja Obradovića 8, 21000 Novi Sad, SERBİA
}

\section{ARTICLE INFO}

Research Article

Corresponding Author: Ranko ČABİLOVSKİ, E-mail: ranko@polj.uns.ac.rs, Tel: +381 (21) 4853310

Received: 28 March 2018, Received in Revised Form: 07 September 2018, Accepted: 14 September 2018

\begin{abstract}
The aim of this research was to determine the influence of drip fertigation on soil chemical properties and vertical distribution of nutrient in the root zone of three apple orchards planted on soils with different textures (loam, clay loam and sandy loam). The fertigation led to a significant decrease in soil $\mathrm{pH}$, concentration of calcium carbonate $\left(\mathrm{CaCO}_{3}\right)$ and organic carbon $(\mathrm{C})$. Changes of these parameters were more pronounced in sandy loam soil than in loam and clay loam. Fine textured soils (loam and clay loam) had higher accumulation of available forms of $\mathrm{P}, \mathrm{K}, \mathrm{Fe}, \mathrm{Zn}, \mathrm{Mn}$ and $\mathrm{Cu}$ in the surface layer at 0-10 cm depth, compared to sandy loam soil. The results showed that, despite numerous advantages, drip system of fertigation can lead to negative changes of soil properties and that the sandy loam soils are more exposed, but in the same time more suitable for fertigation due to better vertical distribution of nutrients in a soil profile compared to loam and clay loam.
\end{abstract}

Keywords: Soil fertility; Irrigation; Nitrogen; Phosphorus; Potassium

(C) Ankara Üniversitesi Ziraat Fakültesi

\section{Introduction}

Irrigation can affect soil quality in different ways. Consequently, monitoring is necessary to avoid negative consequences of irrigation on soil quality in the form of reduced fertility, and crop productivity (Sun et al 2018). The influence of irrigation on physical and chemical soil properties in arid and semi-arid conditions is well documented, while there is very little data on effects of irrigation in humid and sub-humid conditions where crops can be grown without irrigation. In Serbia where the total amount of precipitation and its distribution during the vegetative growth period is highly variable, irrigation is used as an additional tool for supplying plants with water during critical crop growth. One of the most commonly used irrigation system in modern apple orchards is drip irrigation. The main advantage of this system compared to others is that irrigation timing and quantity can be very accurately adjusted to the needs of plants in accordance with plantation age, phenophase and weather conditions (Haynes 1985). The drip system is more efficient than other irrigation systems because the dripping water is added to a relatively small soil volume around the root of the cultivated plants, but at the same time the effect on physical and chemical soil properties in wetted zone 
is more pronounced compared to other systems (Alva \& Obreza 1993). Drip irrigation can have a significant impact on soil fertility due to a change in $\mathrm{pH}$ values of the soil which largely influences the availability of certain soil nutrients and thus their absorption by the plants and the crop productivity (Neilsen et al 1993; Treder et al 1997).

Groundwater (Artesian aquifers) is most commonly used for drip irrigation. Groundwater can contain high concentrations of calcium and magnesium bicarbonate (Čuvardić et al 2004), which lead to an increase in soil $\mathrm{pH}$ value and a lower availability of nutrients. On the other hand, irrigation and fertilizer application through irrigation system (fertigation) can cause soil acidification due to the process of washing out of base cations (Neilsen \& Stevenson 1983), or the application of physiologically acidic fertilizers which lower the soil pH value (Belton \& Goh 1992; Komosa et al 1999). Apart from changes in soil pH value, irrigation can have a negative effect on soil organic matter content. Increased soil moisture has a positive effect on microbiological activity and decomposition of organic matter which can lead to a decrease of soil organic carbon and indirectly to a reduction in soil fertility (Condron et al 2014).

It is well know that soil texture has an important role in nutrient management because it influences nutrient retention (Gaines \& Gaines 1994), water infiltration rate (Mamedov et al 2001), cation exchange capacity (Hepper et al 2006), content of organic matter (Bechtold \& Naiman 2006), and other characteristics that define soil fertility.

The aim of this research was to determine the influence of drip fertigation on soil chemical properties and vertical distribution of nutrients in the root zone of three apple orchards planted on soils with different textures.

\section{Material and Methods}

\subsection{Research site}

Research was conducted on three localities in the northern part of Serbia (Vojvodina province) during
September 2014. The analyzed samples were taken from three farming households with modern apple orchards of the Golden Delicious cultivar. The trees were on M9 T337 rootstock, planted at a $3.2 \times 0.8 \mathrm{~m}$ distance. The orchards were planted in 2007 on soil of different textures (Table 1). The basic chemical properties of the experiment soils are presented in Table 2. In the last seven years, during the vegetation period (from April to September), all three orchards have been watered using drip irrigation with annual irrigation norm from 50 to $150 \mathrm{~mm}$ of water. The chemical composition of the irrigation water is shown in Table 3. In each orchard, the experiment was set up using completely randomized design with four repetitions, where one row of apple trees represented one repetition. During the sevenyear period the fertigation has been conducted in all three orchards using same types and doses of fertilizers: urea $\left(100 \mathrm{~kg} \mathrm{ha}^{-1}\right)$, ammonium nitrate (100-150 kg ha-1), monoammonium phosphate (60$\left.80 \mathrm{~kg} \mathrm{ha}^{-1}\right)$, and potassium sulfate (160-200 $\left.\mathrm{kg} \mathrm{ha}^{-1}\right)$. The total amounts of nitrogen, phosphorus and potassium applied trough fertigation system during each vegetation were: $80-100 \mathrm{~kg} \mathrm{~N}^{-1}, 30-40 \mathrm{~kg}$ $\mathrm{P}_{2} \mathrm{O}_{5}$ ha $^{-1}$ and 80-100 $\mathrm{kg} \mathrm{K}_{2} \mathrm{O} \mathrm{ha}^{-1}$. The application of fertilizers with microelements has been done each year using foliar spraying. The microelements were applied as iron sulphate $\left(4.5 \mathrm{~kg} \mathrm{ha}^{-1}\right)$, zinc sulphate $\left(1.5 \mathrm{~kg} \mathrm{ha}^{-1}\right)$ and manganese sulphate $\left(1.5 \mathrm{~kg} \mathrm{ha}^{-1}\right)$ in the first half of the vegetation every year. Copper was not used as a fertilizer, but copper hydroxide is used every year as a fungicide.

\subsection{Soil sampling and analysis}

During September 2014, soil samples were taken from all three orchards from soil layers at 0-10, 10$20,20-30$ and 30-50 cm depth. Samples were taken from soil that was under irrigation emitter tubing and unirrigated soil of the inter-row spaces at a distance of $1.5 \mathrm{~m}$ from the irrigation tubing. In each site soil sample were taken from four repetitions, and in total 120 samples were analyzed. The soil $\mathrm{pH}$ was determined in soil suspension with $1 \mathrm{M}$ $\mathrm{KCl}$, potentiometrically using a $\mathrm{pH}$ meter (MettlerToledo, Switzerland) (ISO 10390:2007). The content 
Table 1- Soil textures

\begin{tabular}{|c|c|c|c|c|c|c|}
\hline Site & GPS coordinates & $\begin{array}{c}\text { Coarse sand } \\
(\%)\end{array}$ & $\begin{array}{c}\text { Fine sand } \\
(\%)\end{array}$ & $\begin{array}{l}\text { Silt } \\
(\%)\end{array}$ & $\begin{array}{l}\text { Clay } \\
(\%)\end{array}$ & Texture \\
\hline Remeta & $\begin{array}{l}\text { N 45 } 06^{\prime} 03.05^{\prime \prime} \\
\text { E } 19^{\circ} 44^{\prime} 20.08^{\prime \prime}\end{array}$ & 1.0 & 41.0 & 34.0 & 24.0 & Loam \\
\hline Rumenka & $\begin{array}{l}\text { N } 45^{\circ} 17^{\prime} 42.25^{\prime \prime} \\
\text { E } 19^{\circ} 45^{\prime} 28.83^{\prime \prime}\end{array}$ & 0.0 & 31.0 & 33.0 & 36.0 & Clay loam \\
\hline Ljutovo & $\begin{array}{l}\text { N } 45^{\circ} 17^{\prime} 42.25^{\prime \prime} \\
\text { E } 19^{\circ} 45^{\prime} 28.83^{\prime \prime}\end{array}$ & 2.0 & 60.4 & 27.8 & 9.8 & Sandy loam \\
\hline
\end{tabular}

Table 2- Basic chemical characteristics of the soils

\begin{tabular}{lccccccc}
\hline Site & $\begin{array}{c}\mathrm{Ph} \\
\left(\mathrm{H}_{2} \mathrm{O}\right)\end{array}$ & $\begin{array}{c}\mathrm{pH} \\
(\mathrm{KCl})\end{array}$ & $\begin{array}{c}\mathrm{CaCO}_{3} \\
(\%)\end{array}$ & $\begin{array}{c}\text { Total } \mathrm{N} \\
(\%)\end{array}$ & $\begin{array}{c}\text { Organic C } \\
(\%)\end{array}$ & $\begin{array}{c}\mathrm{AL}-\mathrm{P}_{2} \mathrm{O}_{5} \\
\left(\mathrm{mg} 100 \mathrm{~g}^{-1}\right)\end{array}$ & $\begin{array}{c}\mathrm{AL}-\mathrm{K}_{2} \mathrm{O} \\
\left(\mathrm{mg} 100 \mathrm{~g}^{-1}\right)\end{array}$ \\
\hline Remeta & 7.92 & 7.16 & 19.33 & 0.11 & 1.30 & 10.70 & 34.10 \\
Rumenka & 7.54 & 6.56 & 4.15 & 0.13 & 1.55 & 12.10 & 31.80 \\
Ljutovo & 8.36 & 7.79 & 14.34 & 0.09 & 1.09 & 31.80 & 26.80 \\
\hline
\end{tabular}

Table 3- Chemical properties of irrigation water

\begin{tabular}{|c|c|c|c|c|}
\hline \multirow{2}{*}{\multicolumn{2}{|c|}{ Parameters }} & \multicolumn{3}{|c|}{ Sites } \\
\hline & & Remeta & Rumenka & Ljutovo \\
\hline \multicolumn{2}{|c|}{ Dry residue $\left(\mathrm{mg} \mathrm{L}^{-1}\right)$} & 375.00 & 472.20 & 340.00 \\
\hline \multicolumn{2}{|l|}{$\mathrm{pH}$} & 7.42 & 7.35 & 7.31 \\
\hline \multicolumn{2}{|l|}{ SAR* } & 0.76 & 3.17 & 0.93 \\
\hline \multicolumn{2}{|l|}{$\mathrm{EC} \mathrm{dS} \mathrm{m}{ }^{-1}$} & 0.78 & 0.95 & 0.45 \\
\hline \multirow{4}{*}{$\begin{array}{l}\text { Anions } \\
\left(\mathrm{mmol} \mathrm{L}^{-1}\right)\end{array}$} & $\mathrm{CO}_{3}^{2-}$ & 0.20 & 2.14 & 0.20 \\
\hline & $\mathrm{HCO}_{3}^{-}$ & 3.60 & 3.70 & 4.40 \\
\hline & $\mathrm{Cl}^{-}$ & 2.50 & 1.90 & 0.50 \\
\hline & $\mathrm{SO}_{4}^{-}$ & 0.68 & 1.13 & 0.31 \\
\hline \multirow{4}{*}{$\begin{array}{l}\text { Cations } \\
\left(\mathrm{mmol} \mathrm{L}^{-1}\right)\end{array}$} & $\mathrm{Na}^{2+}$ & 1.11 & 4.10 & 1.37 \\
\hline & $\mathrm{K}^{+}$ & 0.16 & 0.11 & 0.05 \\
\hline & $\mathrm{Ca}^{2+}$ & 2.04 & 0.99 & 1.87 \\
\hline & $\mathrm{Mg}^{2+}$ & 2.21 & 2.38 & 2.46 \\
\hline
\end{tabular}

*SAR, sodium adsorption ratio

of calcium-carbonate $\left(\mathrm{CaCO}_{3}\right)$ was determined volumetrically using the Scheibler calcimeter (ISO 10693:2005). The content of organic carbon (C) was determined using the Tyurins method (Tyurin 1940). Mineral $\mathrm{N}$ concentration under field conditions during the vegetation was determined by the Wehrmann \& Scharpf (1979) method. The content of easily available phosphorus and potassium was determined using the AL method (Enger et al 1960). For the determination of plant-available 
fractions of $\mathrm{Fe}, \mathrm{Mn}, \mathrm{Cu}$ and $\mathrm{Zn}$ in the soil, samples were extracted with diethylenetriaminepentaacetic acid-triethanolamine (DTPA-TEA) buffer solution (0.005 M DTPA $+0.01 \mathrm{M} \mathrm{CaC1}_{2}+0.1 \mathrm{M}$ TEA) (ISO 14870:2001). For each sample, $20 \mathrm{~mL}$ of DTPATEA solution was added to $10.0 \mathrm{~g}$ of soil, shaken for $2 \mathrm{~h}$ on an orbital shaker, gravity filtered through filter paper, and analyzed by atomic absorption spectrometer with flame technique (Shimadzu 6300, Japan). The soil texture was determined based on triangle classification of the International Soil Science Society (Verheye \& Ameryckx 1984). The results were subjected to analysis of variance (ANOVA) and treatment means were compared using the Tukey test $(\mathrm{P}<0.05)$ with STATISTICA 9 (StatSoft Inc, USA).

\section{Results and Discussion}

The influence of fertigation on the soil $\mathrm{pH}$, concentration of $\mathrm{CaCO}_{3}$ and organic $\mathrm{C}$ is shown in Figure 1. The fertigation led to a decrease in the soil $\mathrm{pH}$ value in the layers of the wetted zone at $0-10 \mathrm{~cm}$ and $10-20 \mathrm{~cm}$, while the soil acidification intensity differed between the observed sites/soils. The biggest change in soil $\mathrm{pH}$ value was measured in sandy loam soil where there was a decrease of 0.84 $\mathrm{pH}$ units due to fertigation, that is, the soil turned from slightly alkaline class to neutral. Belton \& Goh (1992) and Neilson et al (1993), also reported a considerable decrease in soil $\mathrm{pH}$ value under the drip irrigation system due to the application of physiologically acidic fertilizers such as urea and monoammonium phosphate. The fact that the type of fertilizer greatly influences acidification intensity is also confirmed by Treder (2005). Also, the decrease in soil $\mathrm{pH}$ value can happen as a result of base cation leaching $\mathrm{K}, \mathrm{Ca}$ and $\mathrm{Mg}$, and their replacement in the soil adsorption complex with hydrogen ions (Neilsen \& Stevenson 1983).

In our research, the fertigation led to a significant decrease in concentration of soil $\mathrm{CaCO}_{3}$ in loam and sandy loam soils (Figure 1). On other hand, this effect did not occur in the soil with finer texture (clay loam) (Tables 1 and 2). Considering that the content of organic $\mathrm{C}$ and the share of clay fraction are in correlation with the cation exchange capacity (CEC) (Caravaca et al 1999; Hepper et al 2006), and infiltration rate (Wakindiki \& Ben-Hur 2002), it is possible that due to the higher CEC, and clay fraction the fertigation in clay loam soil did not lead to a significant decrease of $\mathrm{CaCO}_{3}$ content in soil profile under the drip.

Fertigation can have a positive effect on organic $\mathrm{C}$ content in arable land due to a higher production of biomass (root and post-harvest residue of cultivated plants) (Entry et al 2002). On the other hand, due to increased soil moisture and higher microbiological activity, fertigation can lead to a decrease in organic $\mathrm{C}$ content caused by a more intense mineralization (Kumar \& Goh 2000). In our research, measurements of the three experiment soils showed a lower concentration of organic $\mathrm{C}$ in all four layers of the fertigated area of the soil in comparison with the unfertigated area. However, there were statistically significant differences only in the surface soil layer of clay loam, and in all four soil layers of sandy loam soil (Figure 1). The lower concentration of organic $\mathrm{C}$ in the soil under the drip compared to that of the inter-row space is probably the result of more intense mineralization of organic matter caused by more favorable conditions. Other than that, it is possible that a part of the organic $\mathrm{C}$ labile fractions was washed down into deeper soil layers (Kalbitz et al 2000). Supporting this is the fact that the biggest decrease in organic $\mathrm{C}$ content was measured in the sandy loam soil (Ljutovo site) with lighter mechanical composition, higher infiltration rate and deeper wetting layer.

On all three sites, soil samples from the fertigated area (space inside the rows) had higher concentration of mineral $\mathrm{N}$, available $\mathrm{P}$ and $\mathrm{K}$ compared to soil samples from unfertigated area. The concentration of mineral forms of $\mathrm{N}$ did not significantly differ in soil layers, except in loam soil, where surface layer had significantly higher concentration than layer at $30-50 \mathrm{~cm}$ depth. The application of $\mathrm{P}$ fertilizers through fertigation led to an accumulation of phosphorus in surface soil layers of the soils with finer texture (loam and clay loam). In these two soils, an almost double concentration 

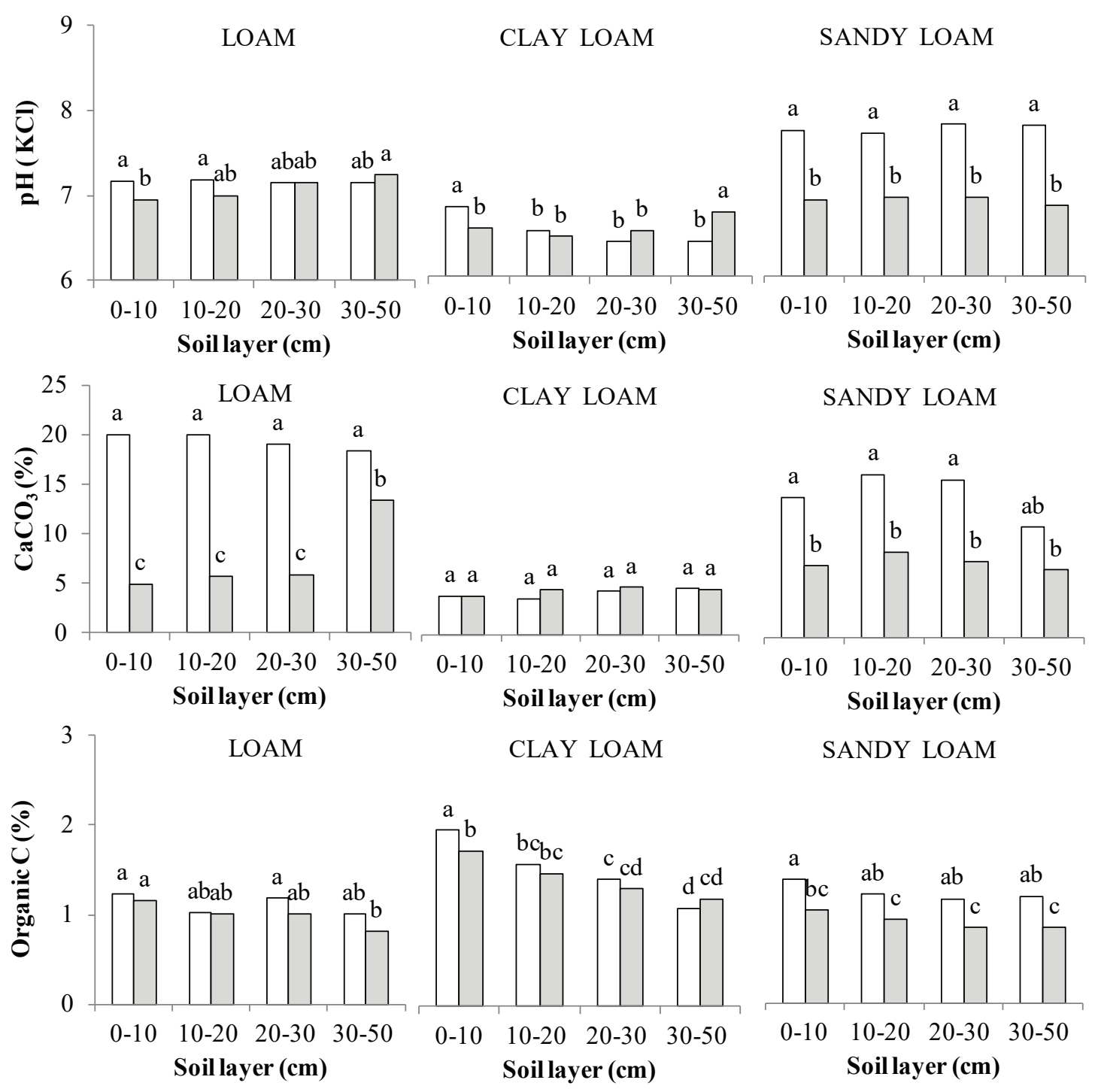

SANDY LOAM

Figure 1- Impact of fertigation on soil $\mathrm{pH}, \mathrm{CaCO}_{3}$ and concentration of organic $\mathrm{C}$ in soils with different texture (gray columns-fertigated soil; white columns-unfertigated soil). Columns followed by different letters indicate LSD at $\mathbf{P} \leq \mathbf{0 . 0 5}$

of available $\mathrm{P}$ and $\mathrm{K}$ was measured in the surface soil layer at $0-10 \mathrm{~cm}$, as opposed to the layer at 10 $20 \mathrm{~cm}$ depth or deeper. On the other hand, at site Ljutovo (sandy loam), a higher concentration of available $\mathrm{P}$ was measured in all four layers on the section that was fertigated, compared to the soil that was not under the direct influence of fertigation. In sandy loam soil was not recorded surface layer accumulation, as was the case in the other two soil textures, where the $0-10 \mathrm{~cm}$ layer contained more than $50 \%$ of the total $\mathrm{P}$ content in the root system zone (soil layer 0-50 cm) (Table 4). 
Table 4- Distribution of available N, $\mathrm{P}$ and $\mathrm{K}$ in fertigated soil (\% of total amount in soil profile 0-50 cm). Values followed by different letters are significantly different at $\mathbf{P}<\mathbf{0 . 0 5}$

\begin{tabular}{lclll}
\hline Site/soil texture & Depth $(\mathrm{cm})$ & $\mathrm{N}$ & $\mathrm{P}_{2} \mathrm{O}_{5}$ & $\mathrm{~K}_{2} \mathrm{O}$ \\
\hline \multirow{3}{*}{ Remeta/loam } & $0-10$ & $28.9 \mathrm{a}$ & $52.3 \mathrm{a}$ & $44.3 \mathrm{a}$ \\
& $10-20$ & $25.9 \mathrm{ab}$ & $22.0 \mathrm{bc}$ & $23.2 \mathrm{~b}$ \\
& $20-30$ & $24.5 \mathrm{ab}$ & $17.4 \mathrm{c}$ & $19.6 \mathrm{bc}$ \\
& $30-50$ & $20.5 \mathrm{~b}$ & $8.20 \mathrm{~d}$ & $12.6 \mathrm{c}$ \\
Rumenka/clay loam & $0-10$ & $25.5 \mathrm{a}$ & $50.9 \mathrm{a}$ & $44.3 \mathrm{a}$ \\
& $10-20$ & $21.9 \mathrm{a}$ & $19.7 \mathrm{~b}$ & $19.8 \mathrm{~b}$ \\
& $20-30$ & $24.7 \mathrm{a}$ & $13.1 \mathrm{~b}$ & $18.3 \mathrm{~b}$ \\
& $30-50$ & $27.7 \mathrm{a}$ & $16.1 \mathrm{~b}$ & $17.4 \mathrm{~b}$ \\
Ljutovo/sandy loam & $0-10$ & $27.0 \mathrm{a}$ & $26.3 \mathrm{a}$ & $31.2 \mathrm{a}$ \\
& $10-20$ & $24.5 \mathrm{a}$ & $30.5 \mathrm{a}$ & $24.8 \mathrm{~b}$ \\
& $20-30$ & $22.2 \mathrm{a}$ & $20.9 \mathrm{~b}$ & $24.4 \mathrm{~b}$ \\
& $30-50$ & $26.2 \mathrm{a}$ & $22.4 \mathrm{~b}$ & $19.4 \mathrm{c}$ \\
\hline
\end{tabular}

It is also well known that soil $\mathrm{CaCO}_{3}$ have a negative effect on phosphorus availability and its movement toward deeper soil layers, due to process of $\mathrm{P}$ precipitation (Tunesi et al 1999). However, in our research $\mathrm{P}$ accumulation (in the surface layer) in the clay loam soil with lower $\mathrm{CaCO}_{3}$ content and finer texture was higher than in the sandy loam soil with higher $\mathrm{CaCO}_{3}$ content and coarser texture. These results indicate that $\mathrm{P}$ movement under the irrigation emitter into the deeper soil layers was far more conditioned by soil texture than $\mathrm{CaCO}_{3}$ content and soil $\mathrm{pH}$ value. The studies of Zheng et al (2003), Salas et al (2003) and Hanson et al (2006) also indicate a great influence of soil texture on phosphorus shift and accumulation.

The available $\mathrm{K}$ distribution in the apple root zone was identical to that of phosphorus. In the soil with coarser texture (sandy loam), the concentration of $\mathrm{K}$ in the deepest soil layer (40$50 \mathrm{~cm})$ at fertigated area was significantly higher compared to corresponding layer at unfertigated area. Simultaneously, in loam and clay loam soils, significant differences in $\mathrm{K}$ concentration were found only in the surface soil layers (Figure 2). Better vertical distribution of $\mathrm{K}$ in sandy loam soil, compared to the other two soil textures is probably the result of coarser soil texture and lower clay content, as it was previously noticed by Rosolema et al (2010), who found that $\mathrm{K}$ movement into deeper soil profile was significant in the lighter textured soil but was not apparent on the heavier textured soil.

The concentrations of available forms of microelements in all the soil samples were above critical values where deficiency symptoms can be expected (Lindsay \& Norvell 1978). The fertigation led to a higher concentration of all the analyzed microelements $(\mathrm{Fe}, \mathrm{Cu}, \mathrm{Zn}, \mathrm{Mn})$, especially in the surface soil layers, although fertilizers containing microelements were not used in the fertigation (Figure 3). The higher concentration of microelements in the soil samples can be explained by the fact that the samples were taken directly under the apple trees (inside the row). Therefore, it is possible that microelements were washed down from the apple tree trunks and leaves and then accumulated in the soil surface within the sampling zone. On the other hand, the use of acidic fertilizers in the fertigation led to a decrease in soil $\mathrm{pH}$ value under the emitter, which could have had a positive effect on the concentration of available forms of microelements (Haynes \& Swift 1987). 

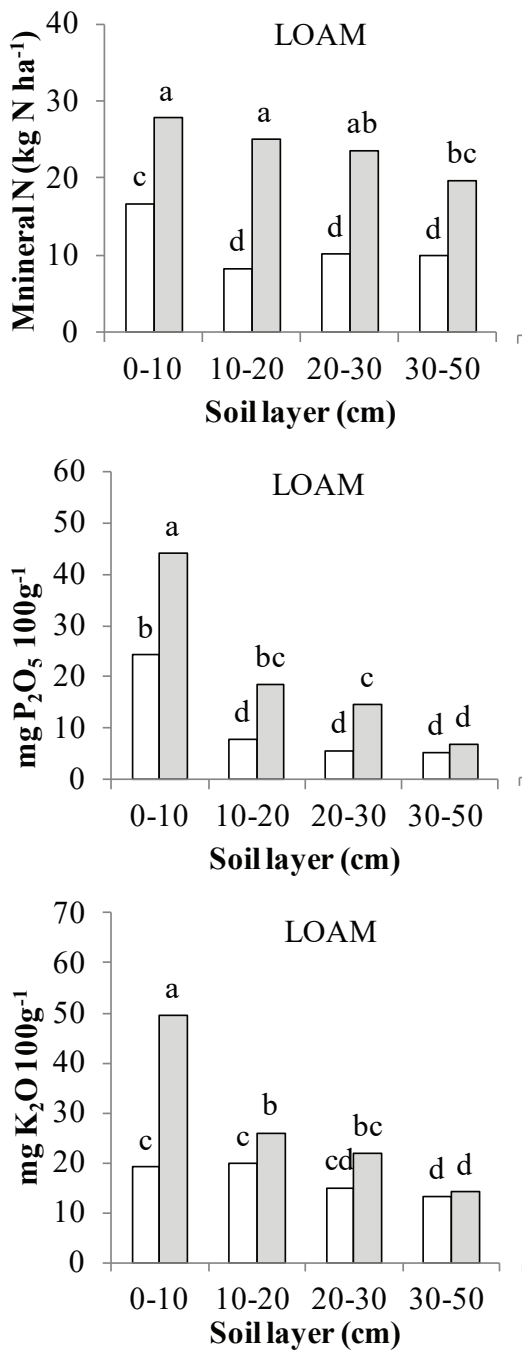

CLAY LOAM

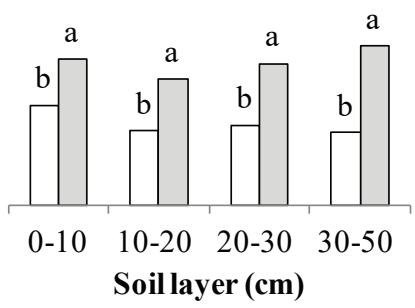

CLAY LOAM
SANDY LOAM

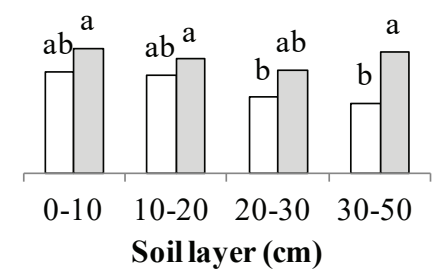

SANDY LOAM
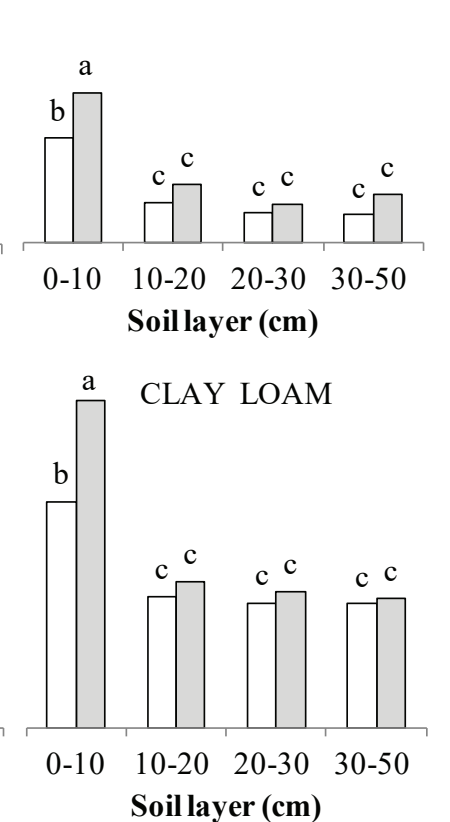

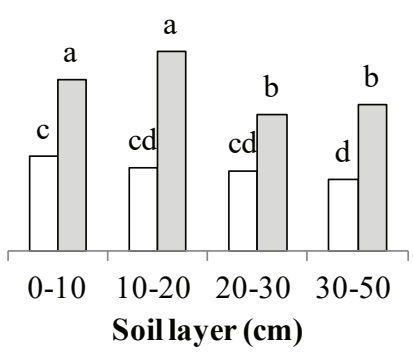

SANDY LOAM

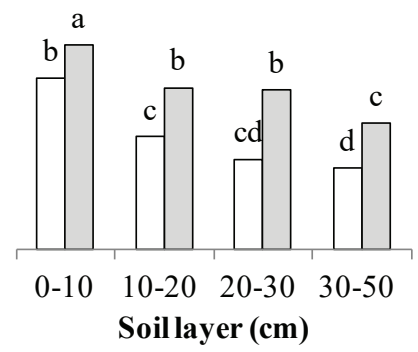

Figure 2- Impact of fertigation on concentration of mineral $N$, available $P$ and $K$ in soils with different texture (gray columns-fertigated soil; white columns-unfertigated soil). Columns followed by different letters indicate LSD at $\mathbf{P} \leq \mathbf{0 . 0 5}$

\section{Conclusions}

Drip fertigation led to a significant decrease in soil $\mathrm{pH}$ values, as well as a lower concentration of $\mathrm{CaCO}_{3}$ and soil organic $\mathrm{C}$. Changes of these fertility parameters in soils with finer texture (loam and clay loam) were recorded in the surface layers $(0-10 \mathrm{~cm}$ and 10-20 cm), while in soil with coarser texture (sandy loam), fertigation had significant effect on all of the analyzed layers down to $50 \mathrm{~cm}$ depth. Fine textured soils (loam and clay loam) had a significant accumulation of available forms of $\mathrm{P}, \mathrm{K}, \mathrm{Fe}, \mathrm{Zn}$, $\mathrm{Mn}$ and $\mathrm{Cu}$ in the surface layer at $0-10 \mathrm{~cm}$ depth, while sandy loam soil had a better distribution these nutrients in soil profile (root system zone $0-50 \mathrm{~cm}$ ) than loam and clay loam. 

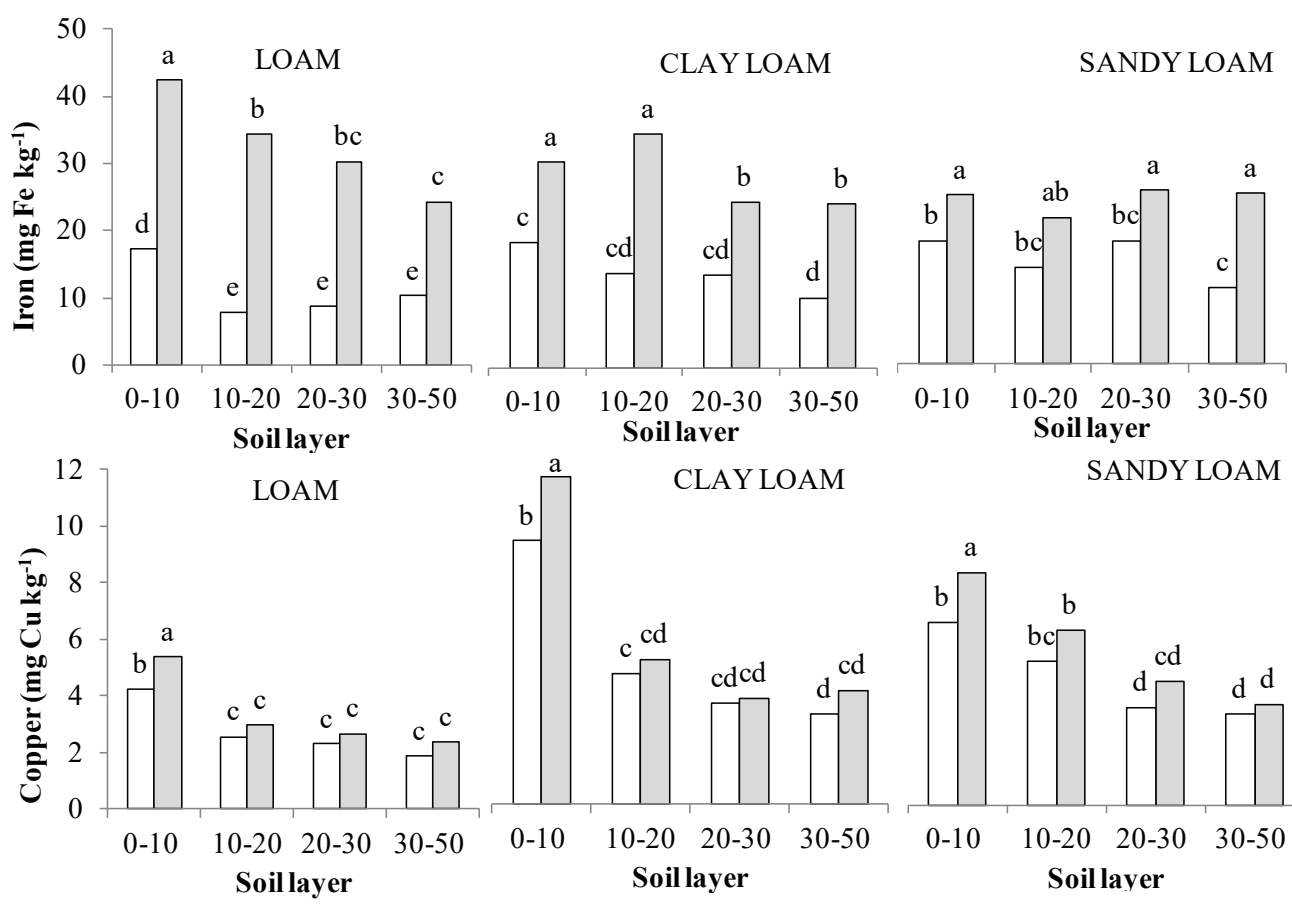

SANDY LOAM
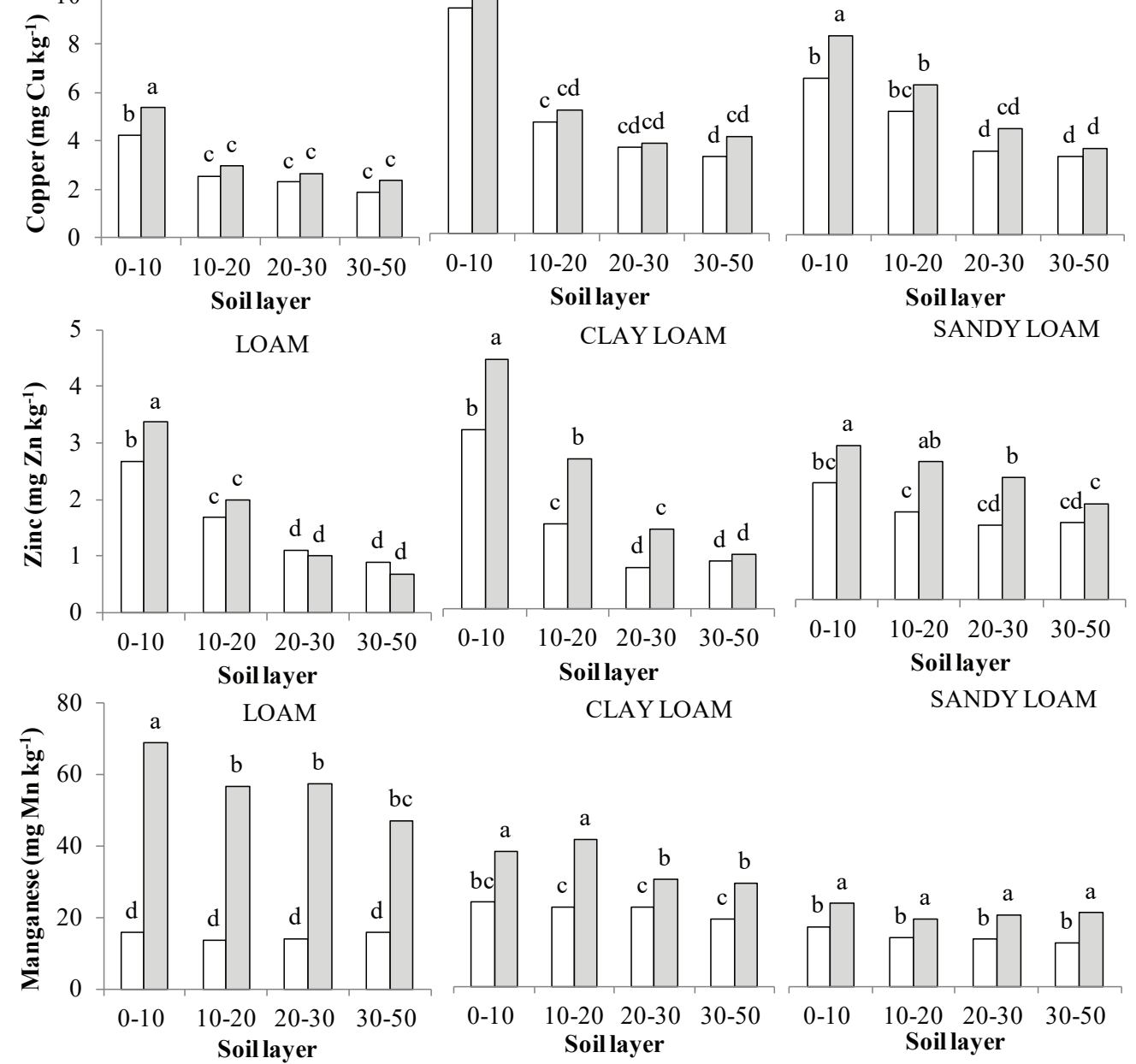

Figure 3- Impact of fertigation on concentration of available microelements (DTPA-extraction) in soils with different texture (gray columns-fertigated soil; white columns-unfertigated soil). Columns followed by different letters indicate LSD at $\mathbf{P} \leq \mathbf{0 . 0 5}$ 
The results showed that, despite numerous advantages, drip system of fertigation can lead to negative changes of soil properties and that the sandy loam soils are more exposed, but in the same time it is more suitable for fertigation due to better nutrients distribution in a soil profile compared to loam and clay loam. However, more detailed research covering a different soil types and orchards with longer period of fertigation is necessary in order to determine changes of soil properties and to take measures to prevent eventual soil degradation.

\section{References}

Alva A K \& Obreza T A (1993). Variation in soil pH and calcium status influenced by mikrosprinkler wetting pattern for young citrus trees. Horticultural Science 28(12): 1166-1167

Bechtold J S \& Naiman R J (2006). Soil texture and nitrogen mineralization potential across a riparian toposequence in a semi-arid savanna. Soil Biology and Biochemistry 38(6): 1325-1333

Belton P R \& Goh K M (1992). Effects of urea fertigation of apple trees on soil $\mathrm{pH}$, exchangeable cations and extractable manganese in a sandy loam soil in New Zealand. Fertilizer Research 33(3): 239-247

Caravaca F, Lax A \& Albaladajo J (1999). Organic matter, nutrient contents and cation exchange capacity in fine fractions. Geoderma 93: 161-176

Condron L M, Hopkins D W, Gregorich E G, Black A \& Wakelin S A (2014). Long-term irrigation effects on soil organic matter under temperate grazed pasture. European Journal of Soil Science 65(5): 741-750

Čuvardić M, Hadžić V, Sekulić P, Kastori R, Belić M, Govedarica M, Nešić L J, Pucarević M \& Vasin J (2004). Quality control of agricultural soils and irrigation water in Vojvodina provance. Ratarstvo $i$ Povrtarstvo 4: 115-127

Enger H, Riehm H \& Domingo W R (1960). Untersuchungen über die shemische Bodenanalyse als Grundlage für die Beurteilung des Nährstoffzustandes der Böden. II Chemische Extrationsmethoden zur Phosphur-und Kaliumbestimmung. Kungliga Lantbrukshögskolans Annaler 26: 199-215

Entry J R, Sojka R E \& Shewmaker G E (2002). Management of irrigated agriculture to increase organic carbon storage in soils. Soil Science Society of America Journal 66: 1957-1964
Gaines T P \& Gaines S T (1994). Soil texture effect on nitrate leaching in soil percolates. Communications in Soil Science and Plant Analysis 25(13-14): 25612570

Hanson B R, Simunek J \& Hopmans J W (2006). Evaluation of urea- ammonium-nitrate fertigation with drip irrigation using numerical modeling. Agricultural Water Management 86: 102-113

Haynes R J (1985). Principles of fertilizer use for trickle irrigated crops. Fertilizer Research 6: 235-255

Haynes R J \& Swift R S (1987). Effect of trickle fertigation with three forms of nitrogen on soil $\mathrm{pH}$, levels of extractable nutrients below the emitter and plant growth. Plant and Soil 102: 211-221

Hepper E N, Buschiazzo D E, Hevia G G, Urioste A \& Anton L (2006). Clay minerology, cation exchange capacity and specific surface area of loess soils with different volcanic ash contents. Geoderma 135: 216223

ISO, International Organization for Standardization. (2001). ISO 14870:2001, Soil quality - Extraction of trace elements by buffered DTPA solution

ISO, International Organization for Standardization. (2005). ISO 10693:2005, Soil quality Determination of carbonate content - Volumetric method

ISO, International Organization for Standardization. (2007). ISO 10390:2007, Soil quality Determination of $\mathrm{pH}$

Kalbitz K, Solinger S, Park J H, Michalzik B \& Matzner E (2000). Controls on the dynamics dissolved organic matter in soils: a review. Soil Science 165(4): 277-304

Komosa A, Pacholak E, Stafecka A \& Treder W (1999). Changes in nutrient distribution in apple orchard soil as the effect of fertigation and irrigation. I Ammonium and nitrates. Journal of Fruit and Ornamental Plant Research 7(1): 27-40

Kumar K \& Goh K M (2000). Crop residues and management practices: effects on soil quality, soil nitrogen, dynamics, crop yield, and nitrogen recovery. Advances in Agronomy 68: 197-319

Lindsay W L \& Norvell W A (1978). Development of a DTPA soil test for zinc, iron, manganese and copper. Soil Science Society of America Journal 42: 421-428

Mamedov A I, Levy G J, Shainberg I \& Letey J (2001). Wetting rate, sodicity, and soil texture effects on infiltration rate and runoff. Australian Journal of Soil Research 39(6): 1293-1305 
Neilsen G H \& Stevenson D S (1983). Leaching of soil calcium, magnesium, and potassium in irrigated orchard lysimeters. Soil Science Society of America Journal 47(4): 692-696

Neilsen G H, Parchomchuk P, Hogue E J, Wolk W D \& Lau O L (1993). Response of apple trees to fertigationinduced soil acidification. Canadian Journal of Plant Science 833: 347-351

Rosolema C A, Sgariboldi T, Garcia R A \& Calonego J C (2010). Potassium leaching as affected by soil texture and residual fertilization in tropical soils. Communication in Soil Science and Plant Analysis 41(16): 1934-1943

Salas A M, Elliot E T, Westfall D G, Cole C V \& Six J (2003). The role of particulate organic matter in phosphorus cycling. Soil Science Society of America Journal 67: 181-189

Sun H, Zhang X, Liu X, Liu X, Ju Z \& Shao L (2018). The long-term impact of irrigation on selected soil properties and grain production. Journal of Soil and Water Conservation 73(3): 310-320

Treder W (2005). Variation in soil pH, calcium and magnesium status influenced by drip irrigation and fertigation. Journal of Fruit and Ornamental Plant Research 13: 59-70

Treder W, Olszewski T \& Cieśliński G (1997). Changes of physico-chemical soil properties as a effect of a drip irrigation of plum trees. Acta Horticulturae 448: 247250

Tunesi S, Poggi V \& Gessa C (1999). Phosphate adsorption and precipitation in calcareous soils: the role of calcium ions in solution and carbonate minerals. Nutrient Cycling Agroecosystems 53: 219227

Verheye W \& Ameryckx J (1984). Mineral fractions and classification of soil texture. Pedologie 2: 215-225

Wakindiki I I C \& Ben-Hur M (2002). Soil mineralogy and texture effects on crust micromorphology, infiltration, and erosion. Soil Science Society of America Journal 66: 897-905

Wehrmann J \& Scharpf H C (1979). Mineral nitrogen in soil as an indicator for nitrogen fertilizer requirements ( $\mathrm{N}_{\text {min }}$-method). Plant and Soil 52: 109-126

Zheng Z, Parent L E \& MacLeod J A (2003). Influence of soil texture on fertilizer and soil phosphorus transformations in Gleysolic soils. Canadian Journal of Soil Science 83: 395-403 